\title{
ANALISIS SISTEM PEMERINTAHAN DI INDONESIA PADA DEMOKRASI DI ERA SBY DAN JOKOWI
}

\author{
Irmaline Pakazeni F ${ }^{\mathbf{1}}$, Cindy Nabilla ${ }^{2}$ \\ ${ }^{1,2}$ Progam Studi Ilmu Pemerintahan, Universitas Indo Global Mandiri,Indonesia. \\ ${ }^{1}$ Email Korespondensi: Irmalinepf4@gmail.com
}

\begin{abstract}
Abstrak: Artikel ini bertujuan untuk melihat bagaimana pekembangan sistem pemerintahan di Indonesia melalui perspektif demokrasi pada era SBY dan Joko Widodo yang dirasa memiliki kendala dan masalah pada beberapa sektor. Untuk mengetahui hasil dari tujuan tersebut, artikel ini mengunakan studi literatur dengan pendektan teoritis yang diambil dari beberapa sumber, baik berita, jurnal maupun buku guna mengambil data-data yang diperlukan. Temuannya adalah pada sistem pemerintahan pada era demokrasi masa kepemimpinan SBY dan Joko Widodo dirasa banyak sekali memliki masalah dalam sistem politik indonesia. Maraknya penyakit birokrasi pun sering terjadi seperti poltik balas budi, hingga Revisi UU ITE serta pelemahan KPK pada masa presiden ke-7 RI Joko Widodo membuat kepercayaan masyarakat terhadap pemerintah menurun. Temuan lainnya ialah data dalam Badan pusat statistik yaitu indeks demokrasi indonesia atau IDI terbilang stabil dan meningkat namun pada praktiknya keresahan dan ketidak percayaan masyarakat terhadap sistem pemerintahan di indonesai khusus nya demokrasi di indonesia semakin nyata.
\end{abstract}

Kata kunci;Sistem Pemerintahan; Demokrasi; SBY dan Jokowi.

Abstract: This article aims to see how the development of the government system in Indonesia through the perspective of democracy in the era of SBY and Joko Widodo. Which is considered to have constraints and problems in several sectors. To find out the results of these objectives, this article uses literature studies with theoretical approvals taken from several sources, both news, journals and books to retrieve the data needed. His findings were that the government system in the democratic era during the leadership of SBY and Joko Widodo was considered to have many problems in the Indonesian political system. The rise of bureaucratic diseases often occurs such as political reciprocation, until the revision of the ITE Law and the weakening of the KPK during the 7th presidential year of the Republic of Indonesia, Joko Widodo, has made public confidence in the government decline. Another finding is the data in the Central Statistics Agency, namely the Indonesian democratic index or IDI is fairly stable and increasing, but in practice the unrest and distrust of the public towards the government system in Indonesia especially democracy in Indonesia is increasingly apparent.

Keywords: Government system; Democracy; SBY and Jokowi.

Article History :

Received 26-08-2020; Revised 01-09-2020; Accepted 28-09-2020

\section{PENDAHULUAN}

Sejak tahun 1945 indonesia dengan resmi menyatakan kemerdekannya. Sejak saat itu indonesia mulai mengatur dan menata sistem pemerintahannya sendiri. Dimulai dengan sistem kabinet parlementer yang dibentuk pertama kali oleh presiden Soekarno pada awal maa kemerdekaan RI hingga sampai dengan saat ini telah beberapa kali indonesia mengalami pergantian sistem kepresidenan serta pergantian jabatan pada sistem pemerintahan Indonesia. Indonesia sebagai negara demokrasi telah mengadopsi konsep Governance dimana di dalamnya melibatkan negara, pasar dan masyarakat sipil dalam menjaga stabilitas negara. 
(Sarmiasih \& Pratama, 2020). Tercatat sejak kemerdekaannya indonesia telah beberapa kali berganti era, dimulai dari masa orde lama pimpinan presiden soekarno, lalu era orde baru yang di pimpin presiden Soeharto, dan era reformasi yang kita lewati sejak era kepemimpinan BJ. Habibie hingga Megawati, lantas bagaimana saat ini sistem pemerintahan di indonesia? dan dikenal sebagai era apa saat? Masihkah kita pantas menyebutnya era reformasi?

Sejarah konstitusi Indonesia dapat dikatakan telah melewati berbagai tahap perkembangan. Tiap tahap memunculkan model ketatanegaraan yang khas, sampai karena trauma masa lalu terutama akibat praktik politik Orde Baru yang menyalahgunakan konstitusi untuk tujuan kekuasaannya yang sentralistik dan otoriter, memunculkan ide untuk mengamandemen UUD 1945. Tahap perkembangan konstitusi di Indonesia dapat dikelompokkan menjadi beberapa periode. Periode pertama berlaku UUD 1945, periode kedua berlaku Konstitusi RIS 1949, periode ketiga berlaku UUDS 1950, Periode keempat berlaku kembali UUD 1945 beserta Penjelasannya. Setelah itu UUD 1945 diubah berturutturut pada tahun 1999, 2000, 2001, 2002 dengan menggunakan naskah yang berlaku mulai 5 Juli 1959 sebagai standar dalam melakukan perubahan di luar teks yang kemudian dijadikan lampiran yang tak terpisahkan dari naskah UUD 1945 (Sartono, 2009).

Sementara itu, menurut Jimly Assidiqie dalam Sartono (2009) membagi menjadi enam tahap konstitusi yang berlaku di indonesia, yaitu: 1) Periode tanggal 18 Agustus $1945-27$ Desember 1949; 2) Periode tanggal 27 Desember 1949 - 17 Agustus 1950; 3) Periode tanggal 17 Agustus 1950 - 5 Juli 1959; 4) Periode tanggal 5 Juli 1959 - 19 Oktober 1999; 5) Periode tanggal 19 Oktober 1999 - 10 Agustus 2002; dan 6) Periode tanggal 10 Agustus 2002 sampai dengan sekarang. Pada periode pertama berlaku UUD 1945, periode kedua berlaku Konstitusi RIS 1949, periode ketiga berlaku UndangUndang Dasar Sementara 1950, Periode keempat berlaku kembali UUD 1945 beserta Penjelasannya. Setelah itu UUD 1945 diubah berturutturut pada tahun 1999, 2000, 2001, 2002 dengan menggunakan naskah yang berlaku mulai 5 Juli 1959 sebagai standar dalam melakukan perubahan di luar teks yang kemudian dijadikan lampiran yang tak terpisahkan dari naskah UUD 1945.

Pada hakikatnya perubahan sistem pemerintahan di indonesia ini juga perpengaruh terhadap perubahan bentuk demokrasi diindonesia tercatat indonesia telah melalui masa dengan sistem demokrasi yang berbeda sebanyak 4 kali dalam sejarah kemerdekaan, yang pertama yaitu pada masa demokrasi liberal di awal kemerdekaan indonesia, kedua adalah demokrasi terpimpin pada era presiden soekarno mengumumkan demokarsi terpimpin dan membubarkan konstituante, ketiga yaitu demokrasi pancasila yang dimulai pada era presiden soeharto, dan terakhir ialah demokrasi pada era saat ini yang dinilai masih dalam tahap transisi. Dalam perkembangannya demokrasi yang dijalankan berdasarkan perwakilan. (Wijaya et al., 2019). Dengan adanya perubahan sistem demokrasi di Indonesia dari masa ke masa ini diharapkan mampun memperbaiki pula sistem pemerintahan di Indonesia.

Berdasarkan history yang telah tercatat bahwa negara indonesia memiliki sistem pemerintahan yaitu presidensil yang artinya presiden sebagai kepala negara sekaligus kepala pemerintahan. Lantas bagaimana peranan tugas dan fungsi lembaga legislatif? Lembaga legislatif sebagai salah satu unsur pemerintahan baik ditingkat pusat maupun ditingkat daerah secara structural menjadi mitra kerja pemerintah pusat dan pemerintah daerah dalam penyelenggaraan pemerintahan. Meskipun antara pemerintah dan lembaga legislatif masingmasing memiliki tugas, wewenang, hak dan kewajiban yang sudah diatur dalam peraturan perundang-undangan yang berlaku. DPRD merupakan lembaga perwakilan rakyat daerah kedudukan sebagai unsur penyelenggaraan pemerintahan daerah memiliki fungsi legislatif, anggaran, dan pengawasan. DPRD mempunyai tugas dan wewenang sebagai berikut : pertama, membentuk perda yang dibahas dengan kepala daerah; kedua, membahas tentang menyetujui rancangan Perda tentang APBD bersama dengan kepala daerah; ketiga, melaksanakan pengawasan terhadap pelaksanaan Perda dan peraturan perundang-undangan 
lainnya, peraturan kepala daerah, APBD, kebijakan pemerintah daerah dalam melaksanakan program pembangunan daerah, dan kerja sama internasional di daerah; keempat, mengusulkan pengangkatan dan pemberhentian kepala daerah/wakil kepala daerah kepada presiden melalui Menteri Dalam Negeri melalui Gubernur/DPRD Kabupaten; kelima, Memilih wakil kepala daerah dalam hal ini terjadi kekosongan jabatan-jabatan daerah wakil kepala daerah; keenam, memberikan pendapat dan pertimbangan kepada pemerintah daerah terhadap rencana perjanjian internasional di daerah; ketujuh, memberikan persetujuan terhadap rencana kerja sama internasional yang dilakukan oleh internasional dan pemerintah daerah; ketujuh, meminta laporan laporan keterangan pertanggungjawaban kepala daerah dalam menyelenggarakan pemerintahan daerah; kedelapan, membentuk panitia pengawas pemilihan kepala daerah; keselakukan pengawasan dan meminta laporan KPUD; kesembilan, memberikan persetujuan terhadap rencana kerjasama antara daerah dengan pihak ketiga yang membebani masyarakat dan daerah. Disamping tugas dan wewenang DPRD mempunyai hak interpelasi, hak angket dan hak menyatakan pendapat (Lumowo: 2017).

Salah satu faktor yang mempengaruhi sistem pemerintahan diindonesia salah satunya ialah dengan peran dari kekuasan itu sendiri secara mendasar kekuasaan lazimnya dipetakan ke dalam beberapa fungsi yang berkaitan satu sama lain. John Locke dalam bukunya "Two Treatises of Government", membagi kekuasaan negara dalam tiga fungsi, tetapi berbeda isinya. Menurut Locke fungsi-fungsi kekuasaan negara terdiri dari; fungsi legislatif, fungsi eksekutif, dan fungsi federatif. Dengan mengikuti jalan pikiran John Locke, Montesquieu dalam bukunya "L'Espirit des Lois" yang ditulis tahun 1784 atau versi bahasa Inggris-nya dikenal "The Spirit of The Laws", mengklasifikasikan kekuasaan negara ke dalam tiga cabang, yaitu 1. Kekuasaan legislatif sebagai pembuat undang-undang; 2. Kekuasaan eksekutif untuk melaksanakan undang-undang. 3. Kekuasaan untuk menghakimi atau yudikatif (Marzuki dalam Yani, 2018).

Berdasarkan uraian diatas penelitian ini akan menjelaskan bagaimana sistem pemerintahan indonesia dan apa saja perbedaan serta perkembangannya dari masa presiden susilo bambang yudhoyono hingga saat ini di masa pemerintahan presiden Joko Widodo. Analisis sistem pemerintahan diindonesia pada artikel ini mengunakan pendekatan teoritis yang bersumber pada studi literatur atau literatur review yang telah penulis kumpulkan melalui beberapa sumber baik dari jurnal-jurnal dan buku-buku yang berkaitan pada topik yang akan dibahas. Sedangkan untuk keperluan analisis pada artikel ini menggunkan ladasan teori sistem pemerintahan, teori pemisahan kekuasan serta teori demokrasi.

Setiap negara pasti mempunyai bentuk sistem pemerintahannya untuk mengatur dan menjalankan urusan pemerintahanya, sebuah sistem pemerintahan berisi sekumpulan aturanaturan dasar mengenai pola kepemimpinan, pola pengambilan keputusan, pola pengambilan kebijakan dan berbagai macam lainnya. Yang berguna untuk menjaga kestabilan pemerintahan dalam bidang politik, ekonomi, pertahanan, dan lainnya (Hendardi, 2017). Sistem pemerintahan itu sendiri memiliki tujuan untuk menjaga ke stabilan masyarakat menjaga tingkah laku kaum mayoritas dan minoritas dan menjaga fondasi pemerintahan, menjaga kekuatan politik, pertahanan , ekonomi, keamanaan sehingga menjadi sistem pemerintahan yang terus-menerus dan demokratis. (hendardi, 2017).

Dari definisi diatas tentu sistem pemerintahan yang baik ialah yang mengaju pada bentuk negara nya. hendardi (2017), dalam bukunya menjelaskan bahwa bentuk sistem pemerintahan diseluruh dunia berbeda-beda, namun dapat digaris besarkan pada 5 golongan utama, yaitu: 1. Presidensial 2. Parlementer 3. Semi Presidensial 4. Komunis, dan 5. Demokrasi Liberal. Setiap sistem pemerintahan memiliki ciri dan gaya nya masing-masing, baik itu ke lebihan maupun kekurangannya. Sistem pemerintahan diindonesia itu sendiri yang dinyatakan dalam konstitusi ialah sistem pemerintahan presidensial, dimana Presiden memiliki dua jabatan tinggi sekaligus ialah sebagai kepala negara dan juga sebagai kepala 
pemerintahan. Bukan hanya itu, Sistem pemerintahan presidensial dicirikan oleh pemilihan kepala eksekutif atau kepala negara secara langsung oleh rakyat, bukan dipilih oleh parlemen seperti yang berlaku pada sistem parlementer. Presiden bukan bagian dari parlemen dan tidak bisa diberhentikan oleh parlemen, kecuali melalui proses pemakzulan (impeachment); dan Presiden tidak dapat membubarkan parlemen sebagaimanan halnya sistem parlementer yang memberi hak kepada kepala negara untuk membubarkan parlemen (Haris, 2011).

Menurut Giovanni Sartori, karakteristik presidensial memiliki tiga ciri utama. Pertama, kepala pemerintahan (presiden) dipilih secara langsung oleh rakyat untuk masa jabatan tertentu. Kedua, dalam masa jabatannya presiden tidak dapat dijatuhkan parlemen. Ketiga, presiden memimpin secara langsung pemerintahan yang dibentuknya (Ismanto dkk, 2004). Bahasannya sistem pemerintahan presidensil ini berangkat dari peran presiden sebagai poros dan pemegang kekuasaan tertinggi disuatu negara tetapi masih dalam kendali rakyat dalam kerangka demokrasi (Wibisono,2014). Di sebuah negara pastilah memiliki ciri politik dan budaya politik yang ada di negara tersebut, ciri dan budaya politik tersebut tertuang dalam bentuk demokrasi yang ada di negara tersebut.

Secara etimologis istilah demokrasi berarti pemerintahan oleh rakyat (demos berarti rakyat; kratos berarti pemerintahan). Tetapi dalam sejarah perkembangannya, istilah demokrasi itu mengandung pengertian yang berbeda-beda. Demokrasi dijelaskan sebagai bentuk pemerintahan dimana hak-hak untuk membuat keputusan-kepuutusan politik digunakan secara langsung oleh setiap warga negara, yang diaktualisasikan melalui prosedur pemerintahan mayoritas, yang biasa dikenal dengan istilah demokrasi langsung. Demokrasi juga dijelaskan sebagai bentuk pemerintahan dimana warga negara menggunakan hak yang sama tidak secara pribadi tetapi melalui para wakil yang duduk di lembaga Dewan Perwakilan Rakyat. Wakil-wakil itu dipilih oleh rakyat dan bertanggung jawab terhadap rakyat. Ini yang disebut demokrasi perwakilan. Atas nama rakyat pejabat-pejabat iitu dapat berunding mengenai berbagai isu masyarakat yang rumit lewat cara bijaksana dan sistematis, membutuhkan waktu dan tenaga (Pratiwi, dkk. 2019).

Menurut Dahl dalam Pratiwi,dkk (2019). terdapat enam prinsip demokrasi yang harus ada dalam sistem pemerintahan, yaitu: 1. Adanya control atau kendali atas keputusan pemerintahan. Pemerintahan dalam mengambil keputusan masih dikontrol oleh lembaga legislative yaitu DPR dan DPRD. Dalam penyusunan kepatutan dan kelayakan (fit and proper test) untuk pengangkatan pejabat negara yang dilakukan oleh pemerintah. 2. Adanya pemilihan yang teliti dan jujur. Demokrasi dapat berjalan dengan baik apabila adanya partisipasi aktif dari warga negara dan partisipasi tersebut dilakukan dengan teliti dan jujur. 3 . Adanya hak memilih dan dipilih. Hak memilih untuk memberikan hak pengawasan rakyat terhadap pemerintahan, serta memutuskan pilihan yang terbaik sesuai dengan tujuan yang ingin dicapai rakyat. Hak dipilih memberikan kesempatan kepada setiap warga negara yang mempunyai kemampuan dan kemauan serta memenuhi persaratan untuk dipilih dalam menjalankan amanat dari warga pemilihnya. 4. Adanya kebebasan menyatakan pendapat tanpa ancaman. Demokrasi membutuhkan kebebasan dalam menyampaikan pendapat, berserikat dengan rasa aman. 5. Adanya kebebasan mengakses informasi. Demokrasi membutuhkan informasi yang akurat, untuk itu setiap warga negara harus mendapatkan akses informasi yang memadai. 6. Adanya kebebasan berserikat yang terbuka. Kebebasan untuk berserikat ini memberikan dorongan bagi warga negara yang merasa lemah, dan untuk memperkuatnya membutuhkan teman atau kelompok dalam bentuk serikat.

Dari definisi dan prinsip di atas maka demokrasi di indonesia dapat kita ketahui terbagi dari berbagai masa ke masa. Terhitung indonesia telah melewati 4 masa pergantian demokrasi dimulai dari masaa demokrasi awal kemerdekaan pada tahun 1945-1959. lalu masa demokrasi terpimpin pada tahun 1959-1965. Masa demokrasi pancasila pada era tahun 1965-1998. hingga saat ini era reformasi yang dimulai pada tahun 1998 sampai dengan saat 
ini. Perjalanan reformasi di indonesia masih berjalan sampai saat ini. Perubahan sistem ketatanegaraan indonesia telah mengubah struktur ketatanegaraan indonesia. Majelis permusyawaratan rakyat yang awalnya menjadi lembaga tertinggi negara berubah statusnya sebagai lembaga tinggi negara. Kedudukna MPR saat ini sejajar dengan lembaga tinggi yang lain seperti BPK, Presiden, DPR. DPD, MA, dan MK. Perubahan juga terjadi di lingkungan yudikatif. Kekuasaan yudikatif bersifat mandiri dan independen tidak berada dibawah eksekutif. Bahkan lemabaga yudikatif memiliki peradilan baru yang disebut mahkamah konstitusi. Tugasnya sebagai penjaga konstitusi dan ketatanegaraan indonesia. Perubahan yang paling mendasar terjadi di lingkungan esksekutif. Presiden dan wakil presiden sebagai pelaksana undang-undang. Masa jabatan presiden dan wakil presiden pun dibatasi maksimal dua periode. (Suryana. 2019).

Proses penglolaan sebuah negara kendatinya harus sesuai dengan falsafah dan hukum tertinggi di negara tersebut, yaitu Pancasila, sebagai nilai-nilai dalam penerapan proses check and blance antar lembaga negara sebagaimana diajarkan dalam teori trias politika atau pemisahan kekuasaan yang dikemukakan oleh montesquieu. Teori ini memberikan pemahaman bahwa kekuasaan pada sebuah pemerintahan yang berdaulat tidak dapat diserahkan kepada orang yang sama dan harus dipisahkan menjadi dua atau lebih kesatuan kuat yang bebas untuk mencegah penyalahgunaan kekusaan oleh pihak yang berkuasa. (Suryana, 2019).

\section{METODE PENELITIAN}

Penelitian ini merupakan gabungan dari 2 metode penelitian yaitu merupakan metode penelitian studi kasus dan metode deskriptif, yang artinya penelitian ini mengambil dan pengelola data melalui fenomena sosial yang nyata di alami berdasarkan kasus-kasus yang ada secara nyata dan di infestigasi secara mendalam dan terperinci. Sementara itu metode pengelolaan data yang diambil pada penelitian ini dengan mengunakan metode kualitaif yang berwujud narasi dan tulisan yang telah peneliti temukan selama mencari data melalui banyak sumber.

Penelitian ini bertujuan untuk mengetahui dan menganalisis sistem pemerintahan di indonesia khusus nya pola demokrasi di indonesia pada masa kepemimpinan presiden indonesia yang ke-enam dan ke-tujuh, Bapak Susilo Bambang Yudhoyono dan Bapak Joko Widodo. Dan mengingatkan kembali bagaimana peranan dan fungsi demokrasi indonesia itu berjalan pada era saat ini sesuai tujuan dan cita-cita yang seharusnya. Sesuai dengan metode yang telah di sampaikan di atas, maka penelitian ini mengunakan metode studi literatur guna mengambil data-data yang di perlukan dari berbagai sumber seperti buku, Jurnal, media elektronik dan hukum negara indonesia yang berkaitan dengan sistem pemerintahan di indonesia pada demokrasi era SBY dan Jokowi.

\section{HASIL DAN PEMBAHASAN}

Bagian ini merupakan bahasan atas temuan dan analisis mengenai sistem pemerintahan di indonesia pada era presiden Susilo Bambang Yudhoyono dan Presiden Joko Widodo, dengan mengunakan pendekatan-pedekatan melalui teori-teori yang telah dipaparkan pada bagian atas artikel ini. Dilihat dari sistem pemerintahan Indonesia periode 2004-2014 yang diampu oleh presiden Susilo Bambang Yudhoyono masih menganut sistem presidensial. Pemerintahan tersebut merupakan pemerintahan pertama di Indonesia hasil dari pemilihan langsung oleh rakyat. Pemilu secara langsung oleh rakyat yang diselenggarakan pada tahun 2004, menghasilkan kursi jabatan presiden kepada Susilo Bambang Yudhoyono bersama wakilnya Jusuf Kalla. Periode SBY ini berlangsung selama 2 periode, karena SBY menang dalam 2 kali pemilihan presiden. 
Krisis moneter warisan orde baru, masih membawa Indonesia ke arah keterpurukan. Bahkan sudah berganti 4 kali presiden, namun terpilihnya SBY memberi sedikit harapan baru bagi Ekonomi Republik Indonesia. Hubungan diplomatik dengan negara lain gencar dilakukan pe-merintah dalam upaya untuk menstabilkan politik dan perekonomian Indonesia. Secara politik, SBY mendapat dukungan koalisi dari 4 partai dan dukungan individu dari partai PAN dan PKB. Namun sebagai balas jasa telah mendukungnya dalam pemilu, maka sesuai kontrak politik harus membagikan jatah kekuasaan dalam infrastruktur politik. Hal seperti itu merupakan asumsi politik Bureaucratic Patrimonialis dan budaya politik patron client terjadi lagi. Dengan mempunyai hak preogratifnya, SBY-JK memilih susunan menteri dalam kabinetnya berasal dari partai-partai pengusungnya.

Posisi presiden dan wakil presiden antara SBY-JK menjadi campur aduk dalam penentuan kebijakan dan tindakan. Jusuf Kalla sebagai wakil presiden melebihi wewenangnya dalam penentuan kebijakan, sehingga terjadi dualisme kepemimpinan yang dipublikasi media. Jusuf Kalla yang merupakan seorang pengusaha, politikus, dan penguasa menjadi lebih mendominasi perpolitikan daripada SBY.JK mengontrol 127 anggota DPR sedangkan SBY hanya mengontrol 56 anggota DPR. Secara politis kekuatan JK lebih besar dibandingkan dengan SBY. Proses rekonstruksi birokrasi di dalam pemerintahan SBY-JK pernah melakukan restrukturisasi kementrian dan dapartemen, hingga restrukturisasi lembaga kepresidenan.

Gaya kepemimpinan SBY tampak sebagai visioner dan intelektual tapi indecisive, sementara Jusuf Kalla tampak sebagai pemimpin yang berani dalam mengambil keputusan dan risiko tapi decisive. Seharusnya ada pembagian wewenang terhadap presiden dan wakil presiden dalam bidang politik, wewenang dalam pelaksanaan dan pengawasan anggaran negara, wewenang perencanaan dan implementasi kebijakan, menata birokrasi di pemerintahan dan keamanan dalam negeri dan luar negeri.

Kekuasaan SBY berlanjut pada periode selanjutnya, kala memenangkan pemilihan presiden tahun 2009 bersama wakilnya Boediono. Yang menjadi rapor merah SBY pada periode keduanya adalah masalah ketidaktransparan pemerintah terhadap publik, ketidakpastian sistem hukum, pemberantasan KKN, dan reformasi birokrasi yang belum mendapatkan titik terangnya. Sampai berakhirnya masa jabatan kepresidenan SBY pada tahun 2014, diselenggarakan pemilihan presiden berikutnya. Terdapat 2 pasangan calon, yaitu Joko Widodo-Jusuf Kalla dan Prabowo Subianto-Hatta Rajasa. Pemilu ini dimenangkan oleh Joko Widodo dan Jusuf Kalla. (Amini, 2019).

Lima tahun setelah berakhirnya masa jabatan presiden susilo bambang yudhoyono atau lebih tepatnya memasuki masa jabatan yang dipimpin oleh presiden Joko Widodo pun juga banyak mendapatkan catatan dalam menjalankan demokrasi melalui sistem pemerintahan indonesia saat ini.

Dalam buku Lima Tahun Maju Bersama yang dirilis Kantor Staf Presiden Republik Indonesia diketahui, selama lima tahun Pemerintahan Jokowi-Jusuf Kalla telah memastikan perlindungan dan rasa aman, pemerintahan yang bersih, kemajuan desa dan daerah-daerah pinggiran serta tegaknya sistem hukum sebagai prioritas dalam pembangunan di bidang politik. Dalam hal stabilitas politik dalam negeri, pemerintahan Jokowi-Jusuf Kalla terus menjaga dengan mewujudkan rasa aman serta memastikan ruang dialog untuk terus meningkatkan kualitas demokrasi.

Berdasarkan data yang dikutip dari Badan Pusat Statistik (BPS), kehidupan demokrasi Indonesia yang diukur dengan Indeks Demokrasi Indonesia (IDI) berdasarkan kebebasan sipil, hak-hak politik, dan lembaga demokrasi terus berada di titik stabil. Pada tahun 2014 Indeks Demokrasi Indonesia tercatat berada pada 73,04 poin. Sementara pada 2015 berada pada 72,82 poin.Pada 2016 IDI ada pada 70,09 poin, 2017 pada 72,11 poin dan 2018 berada pada 72,39 poin. Menurut pemerintah, fluktuasi Indeks Demokrasi Indonesia ini 
berada di titik stabil. Sebagai sebuah gambaran, penting dilihat salah satu indikator kualitas demokrasi yakni partisipasi publik dalam pemilihan umum. (Asmara,2019.)

Di era kepemimpinan Jokowi selama 5 tahun tersebut, penguatan demokrasi seperti diabaikan, namun begitu Presiden Jokowi tetap menyampaikan bahwa kehidupan demokrasi di eranya begitu diperhatikan. Presiden Jokowi menyebutkan bahwa kebebasan pers dan menyampaikan pendapat merupakan pilar demokrasi yang harus tetap dijaga dan dipertahankan. Presiden Joko Widodo menyebutkan bahwa kemajemukan etnis, budaya Indonesia, dan Agama dilindungi oleh konstitusi. Semua warga negara memiliki hak yang sama, kesetaraan. Dan model pemaksaan kehendak berdasarkan unsur SARA atau jumlah massa bukanlah bentuk dari demokrasi.

Buktinya setelah satu periode berlalu, pemerintahan Jokowi dinilai belum signifikan dalam memperkuat demokrasi dan institusi demokrasi. Reformasi sistem kepartaian, pemilu, serta lembaga perwakilan juga belum terjadi. Namun selama 5 tahun memerintah bukan berarti Presiden Jokowi tidak ada melakukan apa-apa untuk memperbaiki demokrasi. Ada salah satu kebijakan Presiden Jokowi yang lumayan menyangkut penguatan institusi demokrasi, yaitu kenaikan bantuan anggaran untuk partai politik. (Wahyuni, 2019.)

Jokowi melakukan serangkaian kebijakan untuk memajukan Republik Indonesia dan berusaha untuk membenahi evaluasi dari era SBY. Mungkin untuk hal transparansi ke publik dan kebebasan pers sudah dapat dibenahi, namun pada terdapatnya Revisi UU ITE pada tahun 2016 yang membelenggu kebebasan pers dan berekspresi. Rezim Jokowi yang banyak melakukan pembangunan infrastruktur negara menciptakan kriminalisasi terhadap masyarakat sipil yang terkena dampak penggusuran rumah dan tanah dalam upaya pembebasan lahan untuk pembangunan. Ini menjadi rapor merah Jokowi, mengingat yang dipermasalahkannya adalah tentang Hak Asasi Manusia.

Pemerintahan Jokowi tidak mampu menaikan ekonomi nasional, hanya stagnan dalam 5\%. Pembengkakan utang luar negeri pun terjadi. Karena tidak ingin terjadi defisit, maka pemerintah berutang. Kebijakan dalam kesejahteraan masyarakat, yaitu dalam penanggulangan dalam masalah pelayanan kesehatan dibentuklah BPJS-Kesehatan. Akan tetapi, dalam merelealisasikannya terdapat deviasi dari persepektif masyarakat. Pelayanan kesehatan kurang efektif dan fasilitas kesehatan yang kurang memadai. Belum lagi akses ke fasilitas kesehatan seperti puskesmas dan rumah sakit belum mampu menjangkau wilayah terpencil di Indonesia.

Penanganan dalam pemberdayaan kualitas SDM di Indonesia dengan mencoba meningkatkan kapabilitas pendidikannya, pemerintah mengeluarkan Kartu Indonesia Pintar untuk membantu mereka yang membutuhkan dana pendidikan. Namun sasaran pembagian Kartu Indonesia Pintar tidak merata, sehingga isu-isu kecemburuan sosial pun terjadi.

Pemerintahan Jokowi tidak berakhir pada tahun 2019, karenanya Jokowi terpilih kembali saat pemilihan presiden tahun 2019 dengan Ma'ruf Amin sebagai wakilnya. Gejolak politik yang terjadi di awal periode kedua kepresidenannya sangat intens dan tinggi sekali. Polemik yang paling besar adalah usaha KPK memberantas korupsi dikriminalisasi oleh politik era Jokowi pada tahun 2019 dengan Revisi UU KPK. Pasal-pasal yang termaksud dalam RUU KPK ini membatasi dan melemahkan pergerakan KPK untuk memberantas korupsi. Hal yang kontroversial lainnya adalah Revisi KUHP yang menimbulkan mosi tidak percaya kepada pemerintah. Pasal-pasal karet yang tidak rasional dijadikan sebuah aturan hukum yang fundamental. Tentu saja ini menuai kritik keras terhadap DPR dan Jokowi. Dari dua aturan fundamental tersebut menimbulkan demonstrasi yang dilakukan ribuan mahasiswa di berbagai daerah dan puncaknya di Senayan di depan Gedung DPR/MPR terjadi di tahun 2019. (Amini, 2019.).

Pasca reformasi, struktur politik dan fungsi politik mungkin mengalami perubahan yang signifikan, tetapi tidak dengan budaya politiknya. Sehingga, menimbulkan paradoks dalam 
sistem politik Indonesia. Budaya politik yang berorientasi pada perebutan kekuasaan yang terjadi dikalangan elit politik telah membuat struktur demokrasi politik tidak berjalan baik. Isu-isu KKN masih kerap terdengar dalam portal media massa. KKN menjadi pekerjaan rumah yang besar bagi setiap presiden di Indonesia. Demokratisasi semakin menurun dan bisa saja hilang seiiring dengan kebijakan otoriternya pemerintah. (Amini, 2019).

Lantas pekembangan demokrasi di indonesia ini pun mempengarui sistem pemerintahan di indonesia itu sendiri. Implementasi pemerintahan presidensial di era reformasi ini nampaknya belum berjalan maksimal. Presiden dihadapkan pada posisi yang dilematis, kompromi dengan parlemen atau berpegang teguh pada prinsip presidensial yang belum sepenuhnya didukung desain politik yang kuat. Kompromi-kompromi sulit dihindari, sehingga menyebabkan sistem presidensial semakin tereduksi karena personalitas dan gaya kepemimpinan presiden yang cenderung kompromistik dan kurang tegas dalam mengambil keputusan. Penguatan sistem presidensial menjadi sangat relevan diwujudkan untuk mengefektifkan penyelenggaraan pemerintahan. Kurang efektifnya pemerintahan Presiden Susilo Bambang Yudhoyono selama dua periode menjadi pelajaran memperkuat sistem presidensial dengan menyederhanakan sistem kepartaian dalam revisi paket undang-undang politik. Memang menciptakan pemerintahan presidensial yang efektif memang tidak mudah. (Wibisono, 2017).

Dari bebarapa kasus diatas maka dapat disimpulkan bahwa setiap sistem pemerintahan yang dijalani oleh masing-masing presiden baik SBY maupun jokowi mempunyari corak demokrasi yang berbeda-beda dan menjadi ciri khas masing-masing. Corak demokrasi tersebut menimbulkan kelebihan dan kekurangannya masing-masing dibeberapa bidang. Yang pertama dari segi gaya kepemimpinan, gaya kepemimpinan presiden ke 6 RI yaitu Susilo bambang yudhoyono dapat dilihat tampak visioner dan berwibawa tegas dan ilektual, sedang kan gaya kepemimpinan Joko Widodo ialah sederhana, dan lebih mengayomi, hal ini dilihat dari cara kampanye dan kegiatan awal setelah menjadi presiden RI yang ke 7 yaitu blusukan.

Hal yang berbeda antara sistem demokrasi di era SBY dan Jokowi ialah sistem politik dan gaya politik nya sendiri. SBY dikenal dengan ketua partai Demokrat nya telah mempersiapkan putra nya untuk mengikuti jejaknya ke dunia politik, sedangkan Jokowi sampai dengan detik ini masih setia berada pada naungan partai PDI dibawah pimpinan Megawati, kedua fenomena ini memunculkan 2 isue yang tak asing lagi, seperti politik dinasti, dan politik-politik kotor lainnya yang menimbulkan ketidak percayaan masyarakat kepada pemerintah.

Dari segi ekonomi dan keadilan sosial pun tedapat beberapa kekurangan seperti sistem ekonomi yang kurang stabil, keamanan dan keutuhan negara, serta hak asasi manusia yang harus diukur lagi. Kesenjangan dalam sistem ekonomi ini pun makin terasa setiap tahunnya, pada era SBY sistem ekonomi mengalami kemunduran karena harga bahan bakar yang terus meningkat setiap tahunnya, namun ini bisa teratasi dengan bantuan-bantuan yang pemerintah berikan. Memasuki periode masa jabatan presiden ke-7 bantuan ini memang tetap ada namun kesenjangan sosial di aspek lain yang melemah seperti hak asasi manusia, maraknya kasuskasus yang bersinggungan dengan HAM dengan salah satunya UU ITE, UU KPK, RUU KUHP yang terkadang membuat pemerintah sepertinya enggan untuk dikeritik dan masyarakat seperti di bungkam dan tidak bisa mengeluarkan aspirasi, dalam arti kata lain pada era Bapak Jokowi yang kata nya keran mengeluarkan aspirasi itu dibuka selebarlebarnya namun nyata nya malah sebaliknya.

Memang betul setiap periode masa jabatan seorang pemimpin akan mengeluarkan ciri khas dan gaya politik nya masing-masing namun sampai dengan detik ini pemerintah sepertinya harus bebena lagi agar sistem politik indonesia pada era ini bisa membaik lagi serta patologi birokrasi dan penyakit demokrasi bisa sedikit berkurang agar dapat 
meningkatkan kepercayaan masyarakat terhadap pemerintah tidak hanya dalam segi politik namun juga dalam segi demokrasi di indonesia.

\section{KESIMPULAN}

Kesimpulan pada artikel ini adalah sistem pemerintahan di indonesia yang tercantum jelas pada konstitusi indonesia itu sendiri ialah menganut sistem presidensial, dimana presiden memiliki dua jabatan sekaligus, ialah sebagai kepala negara dan kepala pemerintahan. Presiden pun dipilih melalui pemilihan langsung oleh rakyat, dan tidak ada kaitannya dengan parlement, parlement tidak bisa memberhentikan presiden kecuali dengan pemakzulan. Secara garis besar presiden sebagai poros pemegang kekuasaan tertinggi tetapi masih dalam kendali rakyat dalam kerangka demokrasi. Pada sistem pemerintahan dalam lingkup demokrasi pada era presiden ke-6 dan ke-7 RI, yaitu Susilo bambang yudhoyono dan Joko Widodo, banyak sekali perubahan demokrasi di indonesia, diawali dengan kinerja dan harapan baik dari bapak SBY yang meningkatkan perekonomian di indonesia, sampai dengan kasus-kasus permainan politik itu sendiri, seperti contoh adanya lobby-lobby politik yang tidak adil dan politik balas budi. Hal ini menyebabkan politik di indonesia pada era SBY ini memburuk pada setiap tahunnya.

Terlebih lagi memasuki era pemerintahan Joko Widodo banyak sekali kasus-kasus politik yang merugikan masyarakat, demokrasi di indonesia terasa semakin di abaikan. Buktinya setelah satu periode berlalu, pemerintahan Jokowi dinilai belum signifikan dalam memperkuat demokrasi dan institusi demokrasi. Reformasi sistem kepartaian, pemilu, serta lembaga perwakilan juga belum terjadi. Belum lagi kasus-kasus fatal seperti revisi UU ITE 2016 yang membuat undang-undang itu rentan untuk di salah artikan, hingga UU pelemahan KPK yang membuat rakyat indonesia mengelurakan mosi tidak percaya terhadap pemerintahan di era Joko Widodo ini. Untuk itu masukan yang mungkin akan berguna bagi pemerintah ialah perbaikan pada sistem politik terlebih dahulu, agar dapat menimbulkan lagi rasa percaya di kalangan masyarakat terhadap kinerja pemerintah itu sendiri, mengingat sistem demokrasi di indonesia pada akhir-akhir ini melalui Badan pusat statistik dalam indeks demokrasi indonesia terbilang stabil dan meningkat namun pada praktiknya keresahan dan ketidak percayaan masyarakat terhadap sistem pemerintahan di indonesai khusus nya demokrasi di indonesia semakin nyata.

\section{REFERENSI}

Amini, Widiana, 2019. Hegemoni Kekuasaan Dalam Sistem Politik Indonesia:Orde Lama, Orde Baru, Era Reformasi. Siliwangi.

Asmara, Rangga Pandu. 2019. Mengukur capaian 5 tahun pemerintahan Jokowi-JK di bidang politik. (https://www.antaranews.com/berita /1119148/mengukur-capaian-5tahun-pemerintahan-jokowi-jk-di- bidang-politik). di akses 6 Mei 2020.

Haris, Syamsuddin (Ed), 1998. Menggugat Pemilihan Umum Orde Baru, Jakarta: Yayasan obor Indonesia. PPW-LIPI

Hendardi, Bagas. 2017. Sistem Pemerintahan Negara Indonesia. Y Yogyakarta: Istana Media.

Ismanto dkk, 2004. Pemilihan Presiden Secara Langsung 2004: Dokumen, Analisis, dan Kritik, Jakarta: Kementerian Riset dan Tehnologi dan Departemen Politik dan Perubahan Sosial CSIS.

Lumowa, Johny. 2017. "Peranan Legislatif Dalam Mekanisme Pemerintahan Daerah Kabupaten Jaya Wijaya." Journal Lyceum 5.1

Pratiwi,Ega.Dkk. 2019. Blusukan Wujud Kepemimpinan Demokratis (Studi $\quad$ Pada Era Kepemimpinan Jokowi). Malang : FIA UB 
Sartono, Kus Eddy. 2009. kajian konstitusi diindonesia dari awal kemerdekaan sampai era reformasi. Yogyakarta: Humanika.

Suryana, Yana. 2019. Demokrasi di Indonesia dalam lintasan waktu. Klaten : Penerbit cempaka putih.

Sarmiasih, M., \& Pratama, P. Y. (2020). DUKUNGAN KOLEKTIF CIVIL SOCIETY DALAM PENGARUSUTAMAAN GERAKAN ANTI KORUPSI DI INDONESIA. TheJournalish: Social and Government, 1(1), 1-11.

Wahyuni, Reza. 2019. Kepemimpinan Demokrasi di Era Pemerintahan Jokowi. (https://www.kompasiana.com/rezawahyuni2338/5dc94f19d541df6efb 4f5383/kepemimpinan-demokrasi-di-era-pemerintahan-jokowi).Di akses 6 Mei 2020.

Wijaya, J. H., Zulfikar, A., \& Permatasari, I. A. (2019). IMPLEMENTASI SISTEM E-VOTING UNTUK MENINGKATKAN KUALITAS DEMOKRASI DI INDONESIA. Jurnal Pemerintahan Dan Kebijakan (JPK), 1(1), 51-59.

Wibisono, Yusuf. 2017. Anomali Praktik Sistem Pemerintahan Presidensial Dan Multipartai Di Awal Pemerintahan Jokowi Tahun 2014. Jakarta: Jurnal Ilmu dan budaya.

Yani, Ahmad. 2018. Sistem Pemerintahan Indonesia: Pendekatan Teori Dan Praktek Konstitusi Undang-Undang Dasar 1945. Jakarta: JIKH 